\title{
Identification of nurseries areas of juvenile Prochilodus lineatus (Valenciennes, 1836) (Characiformes: Prochilodontidae) by scale and otolith morphometry and microchemistry
}

\author{
Esteban Avigliano ${ }^{1,2}$, Roberta Callicó Fortunato ${ }^{1}$, Fernanda Biolé ${ }^{1}$, Alejandro \\ Domanico $^{3,4}$, Silvia De Simone ${ }^{3,4}$, Juan J. Neiff ${ }^{2}$ and Alejandra V. Volpedo ${ }^{1}$
}

\begin{abstract}
The streaked prochilod Prochilodus lineatus (Valenciennes) is a commercially freshwater species from South America, distributed in the Plata basin. In the present work the morphometry (circularity, rectangularity, form factor, OL/OW and ellipticity indices) and chemistry ( $\mathrm{Sr}: \mathrm{Ca}, \mathrm{Ba}: \mathrm{Ca}, \mathrm{Zn}: \mathrm{Ca}$ ) of lapilli otolith, and geometric morphometry of scales of streaked prochilod juveniles, in two sites in the Plata basin (Uruguay River and Estrella Wetland), were compared to determine if they are area-specific and to identify possible breeding areas. Otolith Ba:Ca ratios was $0.017 \pm 0.003 \mathrm{mmol} /$ mol for Uruguay River while for Estrella Wetland individuals was bellow the detection limits. Zn:Ca ratios tended to be higher for the latter $(0.03 \pm 0.002 \mathrm{mmol} / \mathrm{mol})$. Significantly high circularity and low rectangularity values were obtained for Estrella Wetland otoliths $(\mathrm{p}<0.05)$, while no significant differences for form factor, OL/OW and ellipticity were observed between sampling sites. Considering all scale geometric morphometry variables, discriminant analysis showed a good percentage of classification of individuals (90.5\% for Estrella Wetland and $85.7 \%$ for Uruguay River). These results indicate that the otolith microchemisty and morphometry (circularity and rectangularity indices) and scale morphometry are good markers of habitat and represent a potential tool for identification of streaked prochilod nursery areas.
\end{abstract}

El sábalo Prochilodus lineatus (Valenciennes) es una especie de importancia comercial de agua dulce de Sudamérica, distribuida en la cuenca del Plata. En este trabajo se comparó la morfometría (índices de circularidad, rectangularidad, factor de forma, OL/OW y elipticidad) y microquímica (Sr:Ca, Ba:Ca y Zn:Ca) del otolito lapilli, y la morfometría geométrica de las escamas de sábalos juveniles capturados en dos sitios de la cuenca del Plata (Río Uruguay y bañado la Estrella), para determinar si existen diferencias área-especificas e identificar posibles sitios de cría. La relación Ba:Ca del otolito fue $0.017 \pm 0.003 \mathrm{mmol} / \mathrm{mol}$ para el río Uruguay mientras que estuvo por debajo del límite de detección para los individuos del bañado la Estrella. La relación Zn:Ca tendió a ser más alta en el bañado la Estrella $(0.03 \pm 0.002 \mathrm{mmol} / \mathrm{mol})$. Se obtuvieron valores significativamente altos de circularidad y bajos de rectangularidad para el bañado la Estrella $(\mathrm{p}<0.05)$, mientras que no se hallaron diferencias para el factor de forma, OL/OW y elipticidad. Considerando la morfometría geométrica de las escamas, el análisis discriminante mostró buenos porcentajes de clasificación ( $90.5 \%$ para el bañado la Estrella y $85.7 \%$ para el Río Uruguay). Estos resultados indican que la microquímica y morfometría del otolito (índices de rectangularidad y circularidad) y la morfometría de las escamas son buenos marcadores de hábitat y representan una herramienta potencial para la identificación de sitios de cría del sábalo.

Keywords: Connectivity, Geocrochemistry, Geometric morphometrics, Plata Basin, Streaked prochilod.

\section{Introduction}

In the second part of the $\mathrm{XX}^{\text {th }}$ century, world fishery production increased constantly at an average annual rate of $3.2 \%$ (FAO, 2014). In the last 15 years, the annual world fish extraction has remained constant at around 90 million tons per year (FAO, 2014). However, since the 50s, 25\% of world fisheries have collapsed (Mullon et al., 2005). A great number of marine and freshwater commercially important species are cross-border resources. They make vast movements, covering different jurisdictions, national, as well as international. One of the most commercially

\footnotetext{
${ }^{1}$ Instituto de Investigaciones en Producción Animal (INPA-CONICET-UBA), Facultad de Ciencias Veterinarias, Universidad de Buenos Aires, Av. Chorroarín, 280 (C1427CWO), Buenos Aires, Argentina. (EA) estebanavigliano@conicet.gov.ar (corresponding author), (RCF) roberta_cali@yahoo.com.ar, (FB) fernandabiole@hotmail.com, (AVV) avolpedo@fvet.uba.ar ${ }^{2}$ Centro de Ecología Aplicada del Litoral (CONICET), Ruta 5, km 2.5. CC 291, Corrientes, Argentina. (JJN) jj@neiff.com.ar ${ }^{3}$ Dirección de Pesca Continental, Subsecretaría de Pesca y Acuicultura, Ministerio de Agricultura Ganadería y Pesca. Alférez Pareja 125, Buenos Aires, Argentina. (AD) aadomanico@gmail.com, (SDS) sdesimo@minplan.gov.ar ${ }^{4}$ Comisión de Investigaciones Científicas (CIC), Calle 526 s/n, La Plata, Argentina.
} 
important freshwater species in South America is the streaked prochilod Prochilodus lineatus (Valenciennes, 1836), known as "sábalo or corimbatá" in southern South America. This species, distributed in the Plata basin (Paraná, Paraguay, Uruguay, Río de La Plata, Iguazú, Bermejo and Pilcomayo rivers, among others), is exploited by Argentina, Brazil, Bolivia, Paraguay and Uruguay (Espinach Ros \& Fuentes, 2000). The mentioned basin has a natural flooding pulse regime (Neiff \& Malvárez, 1999) associated to the reproductive cycle of the streaked prochilod, involving migrations upstream, followed by spawning in open river waters coupled to the flooding periods as dispersion of eggs mechanism (Sverlij et al., 1993; Espinach Ros \& Sánchez, 2007). The streaked prochilod migrations for food or reproduction are more than $1000 \mathrm{~km}$ long (Bayley, 1973) though there is a lack of statistics on catching of this species for consumption, it is of common knowledge that some countries, like Argentina, have exported 36.000 t/year of streaked prochilod only captured in the lower region of the basin (Espinach Ros \& Sánchez, 2007; Espinach Ros et al., 2008).

In the last decades, studies on the species have intensified, but most research efforts were made in the middle and low section of the Paraná River in Argentina (Fig. 1) (Sverlij et al., 1993; Espinach Ros \& Sánchez, 2007; Espinach Ros, 2008). It is suggested that this region represents the primary breeding area and the most important catching region of the Plata basin. However, in spite of the socioeconomical importance of the resources of the region, others sub-basins like Uruguay River (Argentina, Brazil and Uruguay border) and Pilcomayo River (Argentina, Bolivia and Paraguay border) (Fig. 1) are scarcely studied and managed (Bayley, 1973; Baigún et al., 2012; Comision Administradora del Río Uruguay (CARU), 2010, 2014). In recent years, presence of eggs and larvae of this species has been found in Uruguay River, downwards of the Salto Grande hydroelectric dam (ArgentinaUruguay), suggesting the area as a breeding region (CARU, 2010, 2014). On the other hand, in the Pilcomayo River floodplain, $1,700 \mathrm{~km}$ away, there are records of less than a year old juveniles, suggesting another breeding area nearby (Bayley, 1973).

Identification of nursery areas is a very important tool to generate strategies that ensure efficiency of sustainable management of fisheries (Beck et al., 2001; Colloca et al., 2009). In this sense, preservation and management of nursery areas promote the maintenance of fishery resources, avoiding their decay to irreversible values. This decline could not only compromise the fisheries continuity, but also affect the productive socioeconomic sector that depends on them (Beck et al., 2001). Due to the strong relation between chemistry and morphometry of fish otolith with different environmental features, lately these tools have been widely used to identify breeding areas of different commercially important species (Rooker et al., 2001; Gillanders et al., 2003; Tournois et al., 2013; Avigliano et al.; 2015d;
Bailey et al., 2015; Bouchard et al., 2015). Even though physiological factors can affect incorporation of trace elements in the otolith, temperature and salinity are among the most relevant environmental factors regarding the incorporation of elements in this structure (Campana, 1999; Secor \& Rooker, 2000; Elsdon \& Gillanders, 2002; Martin et al., 2004; Sturrock et al., 2012; Bouchard et al., 2015). The predominant source of most elements to otoliths is the surrounding water (Kerr \& Campana, 2013). Likewise, otolith morphometry is also related to environmental factors as salinity, temperature, depth, among others (Lombarte, 1992; Lombarte et al., 2010; Avigliano et al., 2014; Reichenbacher \& Reichard, 2014).

Given the aforementioned, the aim of this work was to analyze the importance of some microchemical and morphometrical tools to identify possible breeding areas of streaked prochilod Prochilodus lineatus juvenile individuals. For this, morphometry (circularity, rectangularity, form factor, $\mathrm{OL} / \mathrm{OW}$ and ellipticity indices) and chemistry (Sr:Ca, Ba:Ca, Zn:Ca) of lapilli otolith, and geometric morphometry of scales, in two sites in the Plata basin (Uruguay River and Estrella Wetland), were compared to determine if they are area-specific and to identify possible breeding areas.

\section{Material and Methods}

Study area and sample collection. The Plata basin, with area $3,170,000 \mathrm{~km}^{2}$, is among the largest in the world. The most important rivers are the Paraná $(4,000 \mathrm{~km}$ long), Paraguay $(2,600 \mathrm{~km})$, Uruguay (1,800 km long) and Pilcomayo Rivers (1,500 km) (Fig. 1) (Guerrero et al., 1997). These rivers go through 5 South-American countries (Argentina, Bolivia, Brazil, Uruguay and Paraguay). Particularly, the Pilcomayo River rises in Central Bolivia at about 3,200 $\mathrm{m}$ above sea level $\left(19^{\circ} \mathrm{Lat}\right.$. South), flowing approximately south-eastwards through the Cordillera Central of the Eastern Andes and then forms the border between Argentina and Paraguay (Organización de los Estados Americanos (OEA), 1971). In this section, overflowing forms semi-permanent wetlands, like the Estrella Wetland, that functioning as nurseries for the streaked prochilod (OEA, 1971). Uruguay River headwaters are the mountains of the Atlantic Forest of southeast Brazil, becoming then the international boundary between Argentina and Brazil, and in the southeast the boundary between Argentina and Uruguay (Fig. 1). The Plata basin discharges into the Plata River estuary $\left(30,362 \mathrm{~km}^{2}\right)$ with an average discharge of $23,000 \mathrm{~m}^{3} / \mathrm{s}$ towards the Atlantic Ocean (Guerrero et al., 1997).

Fish samples were collected simultaneously between April 2013 and April 2014 using multifilament three-layer nets in the Uruguay River, upstream of the hydroelectric dam of Salto Grande (Salto Grande, Corrientes province, international boundary of Argentina-Brazil) and in the Estrella Wetland, that is an alluvial fun of Pilcomayo 
River at Formosa province, Argentina (Fig. 1). Fish were transported to the laboratory at $4{ }^{\circ} \mathrm{C}$ where they were measured (standard length $=\mathrm{SL}$ ) and the lapilli otoliths were extracted. Also, axial region scales were extracted, washed with distilled water, dried and stored in paper envelopes.

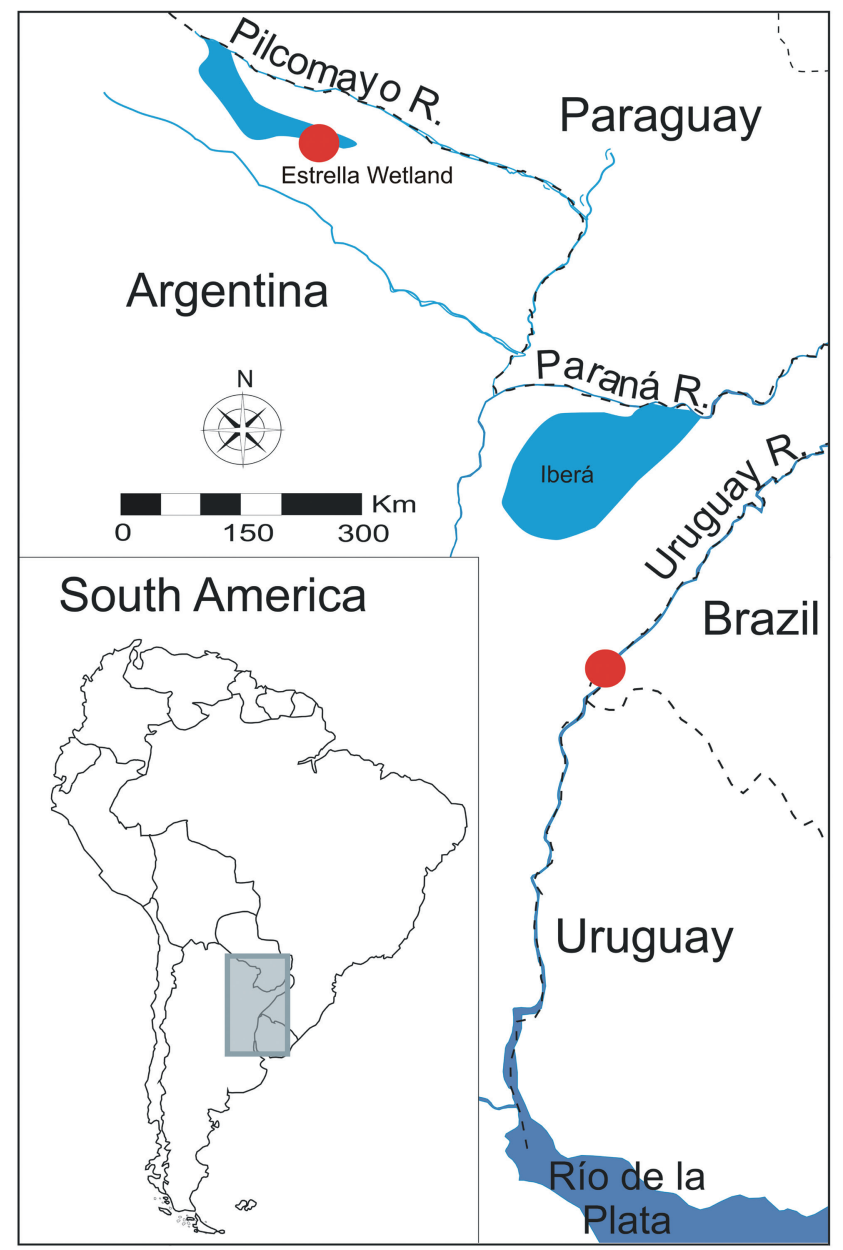

Fig. 1. Study area. The red circles indicate the streaked prochilod (Prochilodus lineatus) collection sites.

Age determination and selection of samples. The otoliths were washed with ultrapure water and dried. The left otolith of each pair was sectioned transversely through the core using a rotary saw equipped with a diamond blade $\left(\right.$ Dremel $^{\circledR} 250$ and 300) and they were burned directly onto a Bunsen burner (Fig. 2). The number of rings in the otolith section was counted using a stereomicroscope (Leica ${ }^{\circledR}$ EZ4HD, Singapore) at $8 \mathrm{X}$ magnification. Age determination by counting the ring number in lapillus otoliths of $P$. lineatus was validated by Espinach Ros et al. (2008). To avoid possible year-class effects on trace element composition or scale and otolith morphometry analysis, only fish $0+$ years old were selected for the study (Fig. 2). In total, 23 individuals from Estrella Wetland site (SL: 19.9 \pm 1.70 ; range: $14-22 \mathrm{~cm}$ ) and 13 from Uruguay River site (SL: 16.4 \pm 2.20 ; range: $13-20 \mathrm{~cm}$ ) were selected for the analysis.

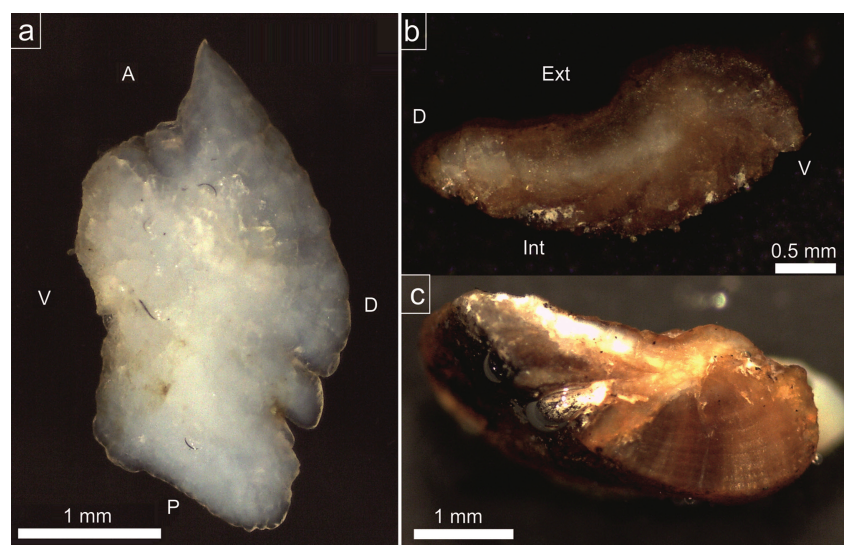

Fig. 2. Lapilli otolith of a streaked prochilod (Prochilodus lineatus). a) Right otolith of one of the sampled individuals, internal view (age $0+$ ); b) right otolith section through the core (age $0+$ ); c) example view of growth rings in an adult fish (age 8+). Abbreviations: A, anterior; D, dorsal; P, posterior; V, ventral; Ext, exterior; Int, interior.

Otolith microchemistry. The right otoliths were washed in water Mili-Q and, once dry, were transferred to a sterile centrifuge tube and weighed using a Sartorius $A G \AA$ ED2242 (Göttingen, Germany) microbalance to the nearest $0.0001 \mathrm{~g}$. Then, otoliths were decontaminated 3 times with $1.7 \% \mathrm{HNO}_{3}$ and finally rinsed 5 times with Milli-Q to remove any contamination from weighing, transferred to new sterile centrifuge tubes and dried overnight in a laminar flow hood.

The otolith were digested with $30 \%$ nitric acid during 24 $\mathrm{h}$ (Avigliano et al., 2015d). The concentration of Sr, Ba, Zn and $\mathrm{Ca}$ were determined (in triplicate) using an inductively coupled plasma optical emission spectrometer (ICP-OES, PerkinElmer Optima 2000 DV, Überlingen, Germany), equipped with a cross-flow nebulizer, Scott chamber, and quartz torch (method 200.7) (U. S. Environmental Protection Agency (USEPA), 1994). The samples were introduced into the equipment with a PerkinElmer AS-90 Plus autosampler. External calibrations were performed in all cases using PerkinElmer Pure Quality Control Standard 21 (QCS 21, USA). Every 10 samples, a blank and a sample of known concentration prepared from the QCS 21 standard were analyzed to determine whether interference or cross-contamination had occurred. The efficiency of the otolith digestion process was verified using certified reference materials (FEBS-1, National Research Council, Canada) and an acceptable recovery percentage was obtained ( $99 \%$ for $\mathrm{Zn}, 100 \%$ for $\mathrm{Ba}, 105 \%$ for $\mathrm{Sr}$ and $\mathrm{Ca}$ ). The detection limits (LOD) in $\mu \mathrm{g} / \mathrm{L}$ based on three times the standard deviation of the blank signal was 8 for $\mathrm{Ba}$ and $\mathrm{Sr}, 12$ for $\mathrm{Zn}$ and 15 for $\mathrm{Ca}$.

The water used throughout the study was obtained from a Milli-Q water purification system (Millipore, São Paulo, Brazil) with a resistivity of $18.2 \mathrm{MOhm} / \mathrm{cm}$.

The results were examined and assessed in relation to the known concentration. The reported results were 
corrected based on a control blank. Concentrations of trace elements were expressed as molar ratios (element: $\mathrm{Ca}$ in $\mathrm{mmol} / \mathrm{mol}$ ) to account for fluctuations in the amount of material analyzed and the loss of material during the preparation process (Sinclair et al., 1998; Bailey et al., 2015).

Otolith morphometry. Prior to digestion, right lapilli otoliths were photographed under a stereoscopic microscope (Leica EZ4 HD). The following morphometric variables were recorded on the images using an image processor (Image-ProPlus 4.5): otolith length (OL), otolith width $(\mathrm{OW})$, and otolith perimeter (OP), in millimeters; and otolith area (OA) in square millimeters. The following shape indices were then calculated: circularity $\left(\mathrm{OP}^{2} / \mathrm{OW}\right)$, rectangularity $(\mathrm{OA} /[\mathrm{OL} \times \mathrm{OW}])$, ellipticity $(\mathrm{OL}-\mathrm{OW} / \mathrm{OL}$ $+\mathrm{OW})$ and form factor $\left(\left[4 \pi \times \mathrm{OA} / \mathrm{OP}^{2}\right]\right)$. The nomenclature of the indices used was taken from Tuset et al. (2003b). Circularity provides information on the complexity of the otolith contour (Tuset et al., 2003b). Rectangularity gives information on the approximation to a rectangular or square shape, a value of 1 indicating a perfect rectangle or square (Tuset et al., 2003b). Ellipticity reflects the similarity to an ellipse, values close to 0 indicating a tendency towards circularity (Tuset et al., 2003b). The form factor is a dimensionless value that indicates the similarity of the otolith contour to a circle; its values range from 0 to 1 , a value of 1 corresponding to a perfect circle (Tuset et al., 2003b).

Scale geometric morphometry. Scales were cleaned with distillated water, dried and photographed using a stereoscopic microscope (Leica EZ4 HD). Only one scale per fish was used for the analysis (Ibañez et al., 2007).

The selection of the landmarks was conducted according to Ibañez et al. (2007) and details of the framework of geometric morphometrics using landmarks can be found in Zelditch et al. (2004).

Landmarks 1 and 3 are the ventro and dorso lateral end of the anterior portion of the scale, respectively; landmark 2 is in the center of the anterior edge of the scale, landmarks 4 and 6 are at the boundary between the anterior area with circuli and the posterior area covered by cteni (spine-like ornamentations), respectively; landmark 5 is the focus of the scale; and landmark 7 is positioned at the tip of the posterior portion of the scale (Ibañez et al., 2007) (Fig. 3).

The configurations of landmark coordinates were scaled, translated, and rotated by a generalized procrustes analysis (GPA) using MorphoJ, TPS util, TPS relw and TPS dig programs (Rohlf, 2001; Klingenberg, 2011).

Statistical analysis. Even though studied fish were of the same age, a Mann-Whitney U test was performed to analyze differences on the SL among sites. This allowed verifying that SL does not affect morphometrical or microchemical variables.

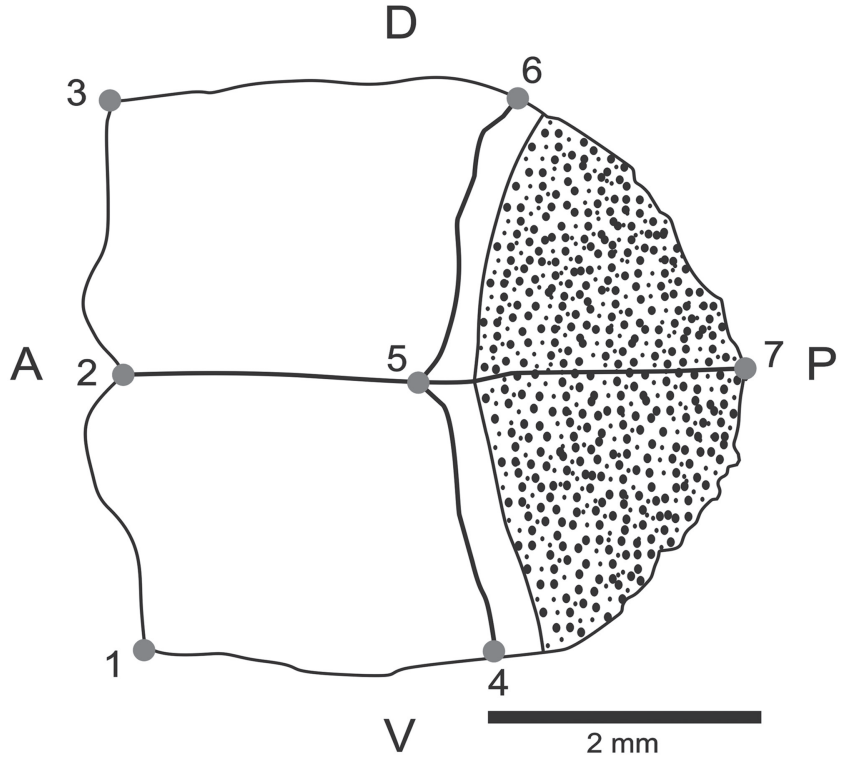

Fig. 3. Landmark definitions used in the fish scales. Abbreviations: A, anterior; D, dorsal; P, posterior; V, ventral.

T-test were used to explore the element:Ca ratios differences between locations. Previously, normality and homogeneity of variance were tested (Shapiro-Wilk test, $\mathrm{p}>0.05$ and Shapiro-Wilk test, $\mathrm{p}>0.05$, respectively). Moreover, we tested for relationships between elemental concentration and fish size (otolith weight) with analysis of covariance (ANCOVA, otolith weight as co-variate) (Campana et al., 2000; Galley et al., 2006; Burke et al., 2008; Longmore et al., 2010; Kerr \& Campana, 2013; Avigliano et al., 2015d, f). Element:Ca ratios were not significantly correlated with otolith mass.

In order to compare the shape indices from the selected sites, two sample tests were applied. After testing normality and homoscedasticity assumptions, circularity, form factor and rectangularity original data series were compared with a t-test while OL/OW and ellipticity were compared with a Mann-Whitney test. This analytical methodology is explained in Avigliano \& Volpedo (2015). ANCOVA was then used to correct the effect of SL on the studied variables. It was only necessary to correct the form factor $(\mathrm{p}<0.01$, constant $=-0.02$ ).

The Hotelling T-square test was applied to determine whether differences existed among sites considering all the morphometric variables simultaneously. This test is appropriate for small samples and is robust to violations of the assumptions of normality and homogeneity of variance (Jørgensen \& Rajeswaran, 2005; Avigliano \& Volpedo, 2015; Avigliano et al., 2015d). A canonical discriminant analysis (DA) was performed using the morphometric variables in order to obtain the cross classification matrix and determine the capacity of these variables to identify the site of origin of the fish (Longmore et al., 2010; Silva et al., 2011). Multicollinearity between variables was analyzed, 
thus preventing a false outcome in the DA analysis and the use of redundant variables in the study (Graham, 2003).

This geometric analysis was performed on the ten Cartesian coordinates or variables of 7 landmarks, reconstructed from distance measurements among the landmarks. Shape variables generated from the landmark analysis were considered to be invariant regarding mathematical differences in translation, rotation, and scale (Márquez et al., 2010). The data matrix was checked and corrected by allometric effects. We used the multivariate regression of shape; size was computed as centroid size (CS), the square root of the sum of squared distances from each landmark to the specimen's centroid (Loy et al., 2000). The relative warps (RW) were used to construct a matrix (W matrix) and a PCA was performed (relative warp analysis, RWA), in order to describe major trends in shape variations (Márquez et al., 2010; Zelditch et al., 2012). RWs were submitted to the cross-validation Discriminant Analysis (DA) to build a predictive model of group membership based on the observed characteristics in each case.

\section{Results}

Sampled fish sizes. No significant differences in the mean SL of fish among locations $(\mathrm{W}=230, \mathrm{p}>0.05)$ was obtained.

Otolith microchemistry. Means, deviations and ranges of otolith element:Ca ratios are shown in Table 1. Given that $\mathrm{Ba}: \mathrm{Ca}$ and $\mathrm{Zn}: \mathrm{Ca}$ ratios were below the detection limits for some groups, statistical tests were not applied for this variables.

While otolith $\mathrm{Ba}: \mathrm{Ca}$ ratios for Uruguay River was $0.017 \pm 0.003 \mathrm{mmol} / \mathrm{mol}$, it was below the detection limit of the used equipment for all Estrella Wetland individuals.
On the other hand, $\mathrm{Zn}: \mathrm{Ca}$ ratios tended to be higher for Estrella Wetland $(0.03 \pm 0.002 \mathrm{mmol} / \mathrm{mol})$, while only 3 samples were above the detection limits in Uruguay River $(0.01 \pm 0.002 \mathrm{mmol} / \mathrm{mol})$.

Sr:Ca ratio differed significantly among sites $(\mathrm{T}=$ 4.25, $\mathrm{p}=0.0002)$, being higher in the Uruguay River site $(1.33 \pm 0.19 \mathrm{mmol} / \mathrm{mol})$ than in the Estrella Wetland $(1.08 \pm 015 \mathrm{mmol} / \mathrm{mol})$.

Otolith morphometry. Significantly high circularity values were obtained for the Estrella Wetland otoliths $(\mathrm{p}=0.002)$, indicating high edge complexity (Table 2). This study site presented otoliths with significantly low rectangularity $(\mathrm{p}=0.04)$ indicating a morphology tending towards circularity, while Uruguay River otoliths tended towards rectangularity. No significant differences for form factor, OL/OW and ellipticity were observed between sampling sites.

The Hotelling's T-square test showed significant differences for the morphometric variables among the study sites $\left(\mathrm{F}_{3,37}=0.60, \mathrm{p}=0.01\right)$. DA showed an acceptable percentage of classification of individuals $(77.7 \%$ for Estrella Wetland and 83.3\% for Uruguay River).

Scale geometric morphometry. Due to the existence of two sets of data, a discriminant canonical function was obtained. Data corresponding to the 10 RWs of the RWA were employed to perform the DA. The DA correctly classified $90.5 \%$ for fish caught in Estrella Wetland, whereas the cross-validated analysis correctly classified $85 \%$ of the fish. The DA proved to have greater accuracy in classifying the fish caught in Uruguay River (85.7\%). In this case, the cross-validated analysis correctly classified was $60 \%$.

Table 1. Mean \pm standard deviation and range (minimum-maximum) in mmol/mol of the otolith ratios of juvenile Prochilodus lineatus for each study site. P: p-value from t-tests. N: sample size. N varied in those sampling sites where some element: Ca ratios were below the detection limit of the used equipment.

\begin{tabular}{|c|c|c|c|c|c|}
\hline & Estrella Wetland & $\mathrm{N}$ & Uruguay River & $\mathrm{N}$ & $\mathrm{P}$ \\
\hline $\mathrm{Ba}: \mathrm{Ca}$ & - & 0 & $0.017 \pm 0.003(0.010-0.023)$ & 13 & - \\
\hline $\mathrm{Sr}: \mathrm{Ca}$ & $1.08 \pm 0.15(0.83-1.33)$ & 28 & $1.33 \pm 0.18(1.06-1.64)$ & 13 & 0.0002 \\
\hline $\mathrm{Zn}: \mathrm{Ca}$ & $0.034 \pm 0.022(0.005-0.083)$ & 17 & $0.015 \pm 0.003(0.013-0.018)$ & 3 & - \\
\hline
\end{tabular}

Table 2. Mean \pm standard deviation and range (minimum-maximum) of the otolith morphometric indices of juvenile Prochilodus lineatus. OL, otolith length; OW, otolith width.

\begin{tabular}{lllll}
\hline & Estrella Wetland & Uruguay River & Statistic & P \\
\hline Circularity & $18.4 \pm 1.02(16.7-19.9)$ & $17.31 \pm 1.08(15.8-18.9)$ & $\mathrm{T}=3.38$ & 0.002 \\
Form factor & $0.17 \pm 0.03(0.10-0.24)$ & $0.17 \pm 0.03(0.12-0.24)$ & $\mathrm{T}=0.44$ & 0.65 \\
Rectangularity & $0.69 \pm 0.07(0.64-0.72)$ & $0.71 \pm 0.02(0.67-0.76)$ & $\mathrm{T}=-2.13$ & $\mathrm{~W}=214$ \\
Ellipticity & $0.20 \pm 0.02(0.17-0.60)$ & $0.20 \pm 0.03(0.17-0.24)$ & $\mathrm{W}=206$ & 0.88 \\
OL/OW & $0.67 \pm 0.05(0.58-0.86)$ & $0.66 \pm 0.04(0.61-0.71)$ & 0.88 \\
\hline
\end{tabular}


The $1^{\text {st }} 3$ RWs explained $69.6 \%(37.4 \%, 20.3 \%$, and $11.9 \%$, respectively) of the total variance for the RWA analysis of the scale shape of the different sampling sites studied. Patterns of morphological variations described by the 1st 3 RWs are shown in Fig. 4. Shape changes along the 1 st RW were expressed by the depression (negative RW1 scores) or expansion (positive RW1 scores) of the scale along the dorso-ventral axis (Fig. 4A). The shape of RW2 varied somewhat due to the displacement of landmarks 4-7, which formed 2 types of scale posterior region: for the 1st one (RW2+), a compression of the antero-posterior axis, while the 2nd one was characterized by an expansion of the scale posterior region.

Shape changes along RW3 were also expressed by depression (RW3+) or expansion (RW3-) of the anterior region (antero-posterior axis) (Fig. 4B).
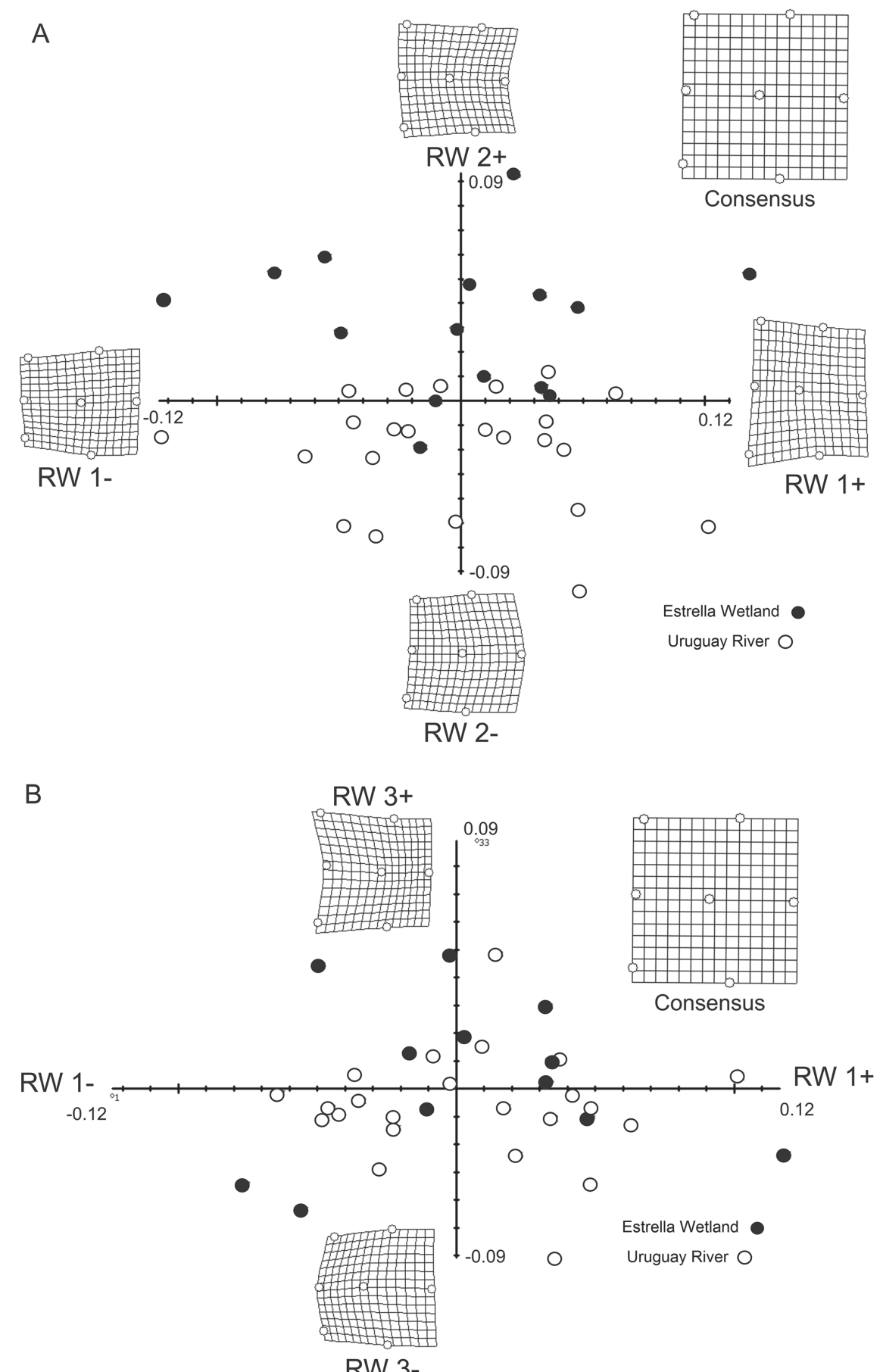

Fig. 4. Relative warp (RW) analysis based on landmark coordinates. Thin plate spline transformation grids for the extreme points of RW are shown; these were superimposed on the shapes predicted when the average landmark configuration of all scales was deformed into that of a hypothetical scale positioned at the extreme of the RW of interest. A) RW2 vs. RW1; B) RW3 vs. RW1. 


\section{Discussion}

Integrated results of this work (scale and otolith morphometry and microchemistry) show that there are different breeding areas in the Plata basin, as it was suggested for the Pilcomayo (Bayley, 1973) and Uruguay Rivers (CARU, 2010). Besides, the simultaneous use of morphometric indices and microchemistry of the otolith, with the geometric morphometric of scales represent a potential tool for identification of streaked prochilod nursery areas.

Tendencies and differences found in element:Ca ratios could be due to diverse factors, like geology of the study area, chemical composition of the water and by less extent to temperature and diet (Campana, 1999; Ranaldi \& Gagnon, 2008; Brown \& Severin, 2009; Sturrock et al., 2012). Given that research on trace element distribution on the study area are scarce and there is not a geochemical distribution map of the location, it becomes difficult to relate elements found in otolith to their geological origin. In the Uruguay River, there has been reports of $\mathrm{Sr}$ concentration in water of around 11-33 $\mu \mathrm{g} / \mathrm{L}$ (Avigliano \& Volpedo, 2013; Avigliano et al., 2014; Avigliano \& Schenone, 2015), while values observed in Estrella Wetland are higher, about 37-104 $\mu \mathrm{g} / \mathrm{L}$ (pers. obs.). However, this pattern was opposite to the one observed in this study for otolith $\mathrm{Sr}$ :Ca ratios (Table 1), not explaining why Uruguay River values were higher.

On the other hand, element incorporation to the otolith does not depend only on geology of the areas. For example, in general, the $\mathrm{Sr}$ concentration in otoliths of freshwater and estuarine fish species correlates positively with the salinity, while Ba correlates negatively (Elsdon \& Gillanders, 2005; Sturrock et al., 2012; Avigliano et al., 2014; Bouchard et al., 2015; Stanley et al., 2015). In this research, the observed pattern in otolith $\mathrm{Sr}: \mathrm{Ca}$ ratios did not coincide with the positive relation between salinity/conductivity and $\mathrm{Sr}: \mathrm{Ca}$ otolith ratio reported for other species (Brown \& Severin, 2009); given that Estrella Wetland normally presents higher conductivity values than Uruguay River ones (130-820 $\mu \mathrm{S} /$ $\mathrm{cm}$ and $<70 \mu \mathrm{S} / \mathrm{cm}$, respectively) (Instituto Nacional de Tecnología Industrial (INTI), 2010; Comisión trinacional para el desarrollo de la cuenca del rio Pilcomayo (CCP), 2014; per. obs.). Nevertheless, relationship between salinity and $\mathrm{Sr}$ concentration in water among study areas was consistent to that reported by other authors (Martin et al., 2004; Elsdon \& Gillanders, 2005; Brown \& Severin, 2009; Sturrock et al., 2012; Avigliano et al., 2014; Bouchard et al., 2015; Stanley et al., 2015). In this sense, Sr levels in superficial water of study areas and their salinities don't seem to explain the observed differences in otolith $\mathrm{Sr}$ :Ca ratios, thus, other factors might be influencing. Experimental essays showed that $\mathrm{Sr}$ precipitation in aragonite is negatively affected by temperature (Kinsman \& Holland, 1969), suggesting that this process may also occur in otoliths (Campana, 1999). This could explain the low $\mathrm{Sr}: \mathrm{Ca}$ ratios obtained for the Estrella Wetland, since its water temperature is usually around $16-35^{\circ} \mathrm{C}$ (CCP2014; per. obs.) while Uruguay River temperatures vary between $14-28^{\circ} \mathrm{C}$
(INTI, 2010). On the other hand, Campana (1999) discussed temperature, major life history transitions, somatic growth rate, and the rate of crystal formation as factors, other than water chemistry, that may influence otolith $\mathrm{Sr}: \mathrm{Ca}$ variation. Campana (1999) proposed that high rates of system-wide protein synthesis extended to endolymph proteins, which are thought to dictate otolith growth. Also, it has been reported that maximum ages and growth rate for Pilcomayo River and Estrella Wetland are lower than those of Uruguay River (Sverlij et al., 1993, pers. obs). High growth rates are thought to reduce Sr incorporation into otoliths, whereas low growth rates are thought to enhance $\mathrm{Sr}$ incorporation (Brown \& Severin, 2009).

Related to Ba levels, superficial water values has been reported around 6.5-13 $\mu \mathrm{g} / \mathrm{L}$ for Uruguay River (Avigliano et al., 2014; Avigliano \& Schenone, 2015), while for Estrella Wetland values are around $26-46 \mu \mathrm{g} / \mathrm{L}$ (pers. obs.). Just as $\mathrm{Sr}: \mathrm{Ca}$ ratios, otolith $\mathrm{Ba}: \mathrm{Ca}$ ratios were higher in Uruguay River fish, not been consistent to observed water levels. However, as it was previously mentioned by other authors (Tabouret et al., 2010; Avigliano et al., 2014; Bouchard et al., 2015), higher Ba:Ca ratios were associated to sites with less conductivity. In this case, otolith $\mathrm{Ba}$ incorporation appears to be independent of water temperature (Martin \& Thorrold, 2005; Martin \& Wuenschel, 2006).

Otolith $\mathrm{Zn}$ incorporation appears to be related to diet (not water) (Ranaldi \& Gagnon, 2008). For this reason, $\mathrm{Zn}: \mathrm{Ca}$ ratio has also been used as habitat indicator for species associated to La Plata River basin such as Percophis brasiliensis (Avigliano et al., 2015b). In this case, relatively elevated $\mathrm{Zn}: \mathrm{Ca}$ ratios found in Estrella Wetland could be associated to geological features of the sampling areas, given that in Pilcomayo River $\mathrm{Zn}$ deposits has been found (Gemmell et al., 1992). Actually, tributaries of Estrella Wetland are contaminated with $\mathrm{Zn}$ due to mining. For example, in its primary tributary, Pilcomayo River, values of up to $6,000 \mu \mathrm{g} / \mathrm{L}$ of $\mathrm{Zn}$ (Fang et al., 2015) were registered, while in Uruguay River no values above $50 \mu \mathrm{g} / \mathrm{L}$ (INTI, 2010; Avigliano \& Schenone, 2015) were detected.

In conclusion, $\mathrm{Sr}$ :Ca ratio showed to be a good habitat indicator. $\mathrm{Ba}: \mathrm{Ca}$ and $\mathrm{Zn}: \mathrm{Ca}$ ratios could also be used as indicators, but it is necessary the use of more sensitive techniques (ICP-MS). It would be interesting to evaluate simultaneous relations with multiparametrical analysis, so as to identify nursery areas more robustly. Differences of $\mathrm{Sr}: \mathrm{Ca}$ ratios and tendencies observed for $\mathrm{Ba}: \mathrm{Ca}$ and $\mathrm{Zn}: \mathrm{Ca}$ ratios may indicate the occurrence of two different breeding sites.

The otolith $\mathrm{Sr}: \mathrm{Ca}$ and $\mathrm{Ba}: \mathrm{Ca}$ ratios proved to be a good marker of habitat for other euryhaline species from La Plata basin, Lycengraulis grossidens (Mai et al., 2014), Odontesthes bonariensis (Avigliano \& Volpedo, 2013; Avigliano et al., 2014) and Micropogonias furnieri (Albuquerque et al., 2012) and anadromus fish, Genidens barbus (Avigliano et al., 2015c, d). However, these relationships depend on the species and should be analyzed before being used in nurseries and fish stock identification studies. 
In relation to the otolith morphometry, only circularity and rectangularity indices were efficient to differentiate breeding areas. These indices showed to be a good tool as habitat indicators for other species of the same basin, like pejerrey O. bonariensis (Avigliano et al., 2015e) and river croaker Plagioscion ternetzi (Avigliano et al., 2015a). The DA classification percentages are similar to those reported by other authors (Tuset et al., 2003a; Avigliano et al., 2015e), who have indicated that the otolith shape indices can be used as natural markers, not only to separate the species, but also to identify populations or nurseries. Circularity was also a good habitat indicator for other species like Coryphaenoides rupestris (Longmore et al., 2010) and Lophius piscatorius (Cañás et al., 2012). On the other hand, form factor did not showed to be a good indicator for the streaked prochilod, as well as for other species like C. rupestris (Longmore et al., 2010). However, form factor index along with ellipticity index, led to the identification of populations of $O$. bonariensis (Avigliano et al., 2015e). These discrepancies among different species show that the use of morphologic indices to separate breeding areas or populations is species and/or environmentally dependent, and should be correctly evaluated before their use for monitoring or population studies.

Even though some variables were alone not efficient to separate breeding areas, simultaneous use of all variables (DA) showed good classification percentages. For this, the use of morphometrical indices cannot be discarded for studies on nursery areas of streaked prochilod.

Environmental (salinity, water temperature and depth) and genetic factors have been suggested to be responsible for some inter- and intra-specific differences in the otolith morphometry (Lombarte, 1992; Lombarte et al., 2010; Avigliano et al., 2014; Reichenbacher \& Reichard, 2014). Therefore, the taxonomic value of otoliths is well established (Gierl et al., 2013; Reichenbacher \& Reichard, 2014). Because of these characteristics, otolith morphometry has been widely used to identify fish stocks (Campana \& Casselman, 1993; Cañás et al., 2012), to differentiate species (Tuset et al., 2012, 2013; Zhuang et al., 2014), to describe ecomorphological patterns of species (Tuset et al., 2003a; Jaramillo et al., 2014; Avigliano et al., 2016), and as an environmental indicator (Nelson et al., 1994; Avigliano et al., 2016). Among the most commonly used indexes are rectangularity, circularity and aspect ratio (Longmore et al., 2010; Cañás et al., 2012; Jaramillo et al., 2014; Avigliano et al., 2016).

The analysis of scale morphometrics was robust to differentiate breeding areas. This technique, unlike the other studied ones, is more economical, requires less work and permits to liberate fish afterwards. Finally, its use could be recommended for study and monitoring of vulnerable species, allowing the capture larger simple volumes and freeing specimens.

The use of geometrical morphometry of scales has been used to identify species (Ibañez et al., 2007) and populations
(Staszny et al., 2012). Moreover, some authors have used Fourier elliptic analysis on scales to identify populations (Richards \& Esteves, 1997; Poulet et al., 2005). However, no morphologic aspect of scales has been previously used as habitat marker to identify breeding areas. There is only one precedent were it was shown that morphology of scales of streaked prochilod juveniles captured close to Estrella Wetland could vary with different hydrologic conditions (Bayley, 1973).

In relation to the obtained results, we recommend to integrate methodologies to identify and monitor streaked prochilod breeding areas in the national and international management programs of the region. For a proper longterm management of fisheries, it is necessary to evaluate if these areas are maintained in time or if they vary in different regions of the basin. This information could be obtained by an annual repetition of this study after reproductive periods. With this gathered information, stable nursery areas could be protected during spawning and breeding phases. However, if some nurseries are not stable in time, is advisable an active monitoring to ensure their identification every year and to act accordingly to guarantee the reproduction and breeding of streaked prochilod juveniles.

In relation to monitoring and use of otolith microchemistry, analyzing the geochemical origin of different studied elements, as well as the incorporation of isotopical relations could generate other markers of origin to study even adult individuals (Ashford \& Jones, 2007; Walther \& Thorrold, 2009; Niklitschek et al., 2010; Hegg et al., 2013, 2015; Garcez et al., 2015).

On the other hand, these methodologies could be used to evaluate the existence of nursery areas in others areas, for example, Uruguay River high basin and in Paraná River, allowing a proper conservation and management of the areas according to fisheries needs. Also, the use of some or all applied methodologies could be helpful for the study of connectivity between nursery areas.

Finally, data generated in relation to the chemical signature of the areas could be used in the near future to predict the origin of adult fish captured in other regions of the basin, using specialized software (e.g. HISEA). For this, otolith cores of adults of the same cohort (2013-2014) could be compared with the chemical signature obtained in this research.

\section{Acknowledgements}

Authors thank to CONICET, Universidad de Buenos Aires (UBACYT 20620110100007), CONICET (PIP11220120100543CO) and Dirección de Pesca Continental, Subsecretaría de Pesca y Acuicultura, Ministerio de Agricultura Ganadería y Pesca, for financial and logistic support. We also thank the Editor and anonymous reviewers for their constructive comments, which helped us to improve the manuscript. 


\section{References}

Albuquerque, C. Q., N. Miekeley, J. H. Muelbert, B. D. Walther \& A. J. Jaureguizar. 2012. Estuarine dependency in a marine fish evaluated with otolith chemistry. Marine Biology, 159: 22292239.

Ashford, J. \& C. Jones. 2007. Oxygen and carbon stable isotopes in otoliths record spatial isolation of Patagonian toothfish (Dissostichus eleginoides). Geochimica et Cosmochimica Acta, 71: 87-94.

Avigliano, E., G. Comte, J. J. Rosso, E. Mabragaña, P. D. Rosa, S. Sanchez, A. Volpedo, F. Rosso \& N. F. Schenone. 2015a. Identificación de stocks pesqueros de la corvina de río (Plagioscion ternetzi) de los ríos Paraguay y Paraná, mediante el análisis morfométrico de sus otolitos. Latin American Journal of Aquatic Research, 43: 718-725.

Avigliano, E., L. A. Jawad \& A. V. Volpedo. 2016. Assessment of the morphometry of saccular otoliths as a tool to identify triplefin species (Tripterygiidae). Journal of the Marine Biological Association of the United Kingdom, 96: 1167-1180.

Avigliano, E., C. F. R. Martinez \& A. V. Volpedo. 2014. Combined use of otolith microchemistry and morphometry as indicators of the habitat of the silverside (Odontesthes bonariensis) in a freshwaterestuarine environment. Fisheries Research, 149: 55-60.

Avigliano, E., M. B. Saez, R. Rico \& A. V. Volpedo. 2015b. Use of otolith strontium:calcium and zinc:calcium ratios as an indicator of the habitat of Percophis brasiliensis Quoy and Gaimard, 1825 in the southwestern Atlantic Ocean. Neotropical Ichthyology, 13: 187-194.

Avigliano, E. \& N. F. Schenone. 2015. Human health risk assessment and environmental distribution of trace elements, glyphosate, fecal coliform and total coliform in Atlantic Rainforest mountain rivers (South America). Microchemical Journal, 122: 149-158.

Avigliano, E., G. Velasco \& A. V. Volpedo. 2015c. Use of lapillus otolith microchemistry as an indicator of the habitat of Genidens barbus from different estuarine environments in the southwestern Atlantic Ocean. Environmental Biology of Fishes, 98: 1623-1632.

Avigliano, E., G. Velasco \& A. V. Volpedo. 2015d. Assessing the use of two southwestern Atlantic estuaries by different life cycle stages of the anadromous catfish Genidens barbus (Lacépède, 1803) as revealed by $\mathrm{Sr}: \mathrm{Ca}$ and $\mathrm{Ba}: \mathrm{Ca}$ ratios in otoliths. Journal of Applied Ichthyology, 31: 740-743.

Avigliano, E., P. Villatarco \& A. V. Volpedo. 2015e. Otolith Sr:Ca ratio and morphometry as indicators of habitat of a euryhaline species: The case of the silverside Odontesthes bonariensis. Ciencias Marinas, 41: 189-202.

Avigliano, E. \& A. V. Volpedo. 2015. Microquímica de otólitos: conceitos, métodos e aplicações. Pp. 333-347. In: Volpedo, A. V. \& A. M. Vaz-dos-Santos (Eds.) Métodos de estudos com otólitos: princípios e aplicações. Buenos aires, CAFP-BAPIESCI.

Avigliano, E. \&A. V. Volpedo. 2013. Use of otolith strontium:calcium ratio as an indicator of seasonal displacements of the silverside (Odontesthes bonariensis) in a freshwater-marine environment. Marine and Freshwater Research, 64: 746-751.
Baigún, C. R. M., D. Colautti, H. L. López, P. A. Van Damme \& R. E. Reis. 2012. Application of extinction risk and conservation criteria for assessing fish species in the lower La Plata River basin, South America. Aquatic Conservation: Marine and Freshwater Ecosystems, 22: 181-197.

Bailey, D. S., E. Fairchild \& L. H. Kalnejais. 2015. Microchemical signatures in juvenile winter flounder otoliths provide identification of natal nurseries. Transactions of the American Fisheries Society, 144: 173-183.

Bayley, P. B. 1973. Studies on the migratory characin, Prochilodus platensis Holmberg 1889, (Pisces, Characoidei) in the River Pilcomayo, South America. Journal of Fish Biology 5: 25-40.

Beck, M. W., K. L. Heck, K. W. Able, D. L. Childers, D. B. Eggleston, B. M. Gillanders, B. Halpern, C. G. Hays, K. Hoshino, T. J. Minello, R. J. Orth, P. F. Sheridan \& M. P. Weinstein. 2001. The identification, conservation \& management of estuarine and marine nurseries for fish and invertebrates. BioScience, 51: 633-641.

Bouchard, C., S. R. Thorrold \& L. Fortier. 2015. Spatial segregation, dispersion and migration in early stages of polar cod Boreogadus saida revealed by otolith chemistry. Marine Biology, 162: 855-868.

Brown, R. J. \& K. P. Severin. 2009. Otolith chemistry analyses indicate that water $\mathrm{Sr}: \mathrm{Ca}$ is the primary factor influencing otolith $\mathrm{Sr}: \mathrm{Ca}$ for freshwater and diadromous fish but not for marine fish. Canadian Journal of Fisheries and Aquatic Sciences, 66: 1790-1808.

Burke, N., D. Brophy \& P. A. King. 2008. Otolith shape analysis: its application for discriminating between stocks of Irish Sea and Celtic Sea herring (Clupea harengus) in the Irish Sea. ICES Journal of Marine Science, 65: 1670-1675.

Campana, S. E. 1999. Chemistry and composition of fish otoliths: pathways, mechanisms and applications. Marine Ecology Progress Series, 188: 263-297.

Campana, S. E. \& J. M. Casselman. 1993. Stock discrimination using otolith shape analysis. Canadian Journal of Fisheries and Aquatic Sciences, 50: 1062-1083.

Campana, S. E., G. A. Chouinard, J. M. Hanson, A. Fréchet \& J. Brattey. 2000. Otolith elemental fingerprints as biological tracers of fish stocks. Fisheries Research, 46: 343-357.

Cañás, L., C. Stransky, J. Schlickeisen, M. P. Sampedro \& A. C. Fariña. 2012. Use of the otolith shape analysis in stock identification of anglerfish (Lophius piscatorius) in the Northeast Atlantic. ICES Journal of Marine Science, 69: 250256.

Comision Administradora del Río Uruguay (CARU). 2010. Programa de conservación de la fauna íctica y los recursos pesqueros del río Uruguay. Informe anual 2009. Available from: http://www.caru.org.uy/web/pdfs_publicaciones/ Programa\%20De\%20Conservacion $\% 20 \mathrm{De} \% 20 \mathrm{La} \% 20$ Fauna $\% 20$ Ictica $\% 20$ Y \% 20 L os $\% 20$ Recursos $\% 20$ Pesqueros\%20Del\%20Rio\%20Uruguay.pdf. (Date of access - 31 March 2016).

Comisión Administradora del Río Uruguay (CARU). 2014. Programa de conservación de la fauna íctica y los recursos pesqueros del río Uruguay. Informe Bianual de Pesca 2010- 
2011. Available from: http://www.caru.org.uy/web/pdfs publicaciones/INFORME\%20PESCA\%20\%202010\%20\%20 11.pdf. (Date of access - 31 March 2016).

Comisión Trinacional para el desarrollo de la cuenca del rio Pilcomayo (CCP). 2014. Informe técnico de la primera campaña extensiva de monitoreo de calidad de aguas. Comisión Trinacional para el Desarrollo de la Cuenca del Río Pilcomayo. Available from:http://www.pilcomayo.net/media/ uploads/informe_tecnico_cali/INFORME_TECNICO_DE_ LA_PRIMERA_CAMPANA_INTENSIVA_2014.pdf (Date of access -31 March 2016).

Colloca, F., V. Bartolino, G. J. Lasinio, L. Maiorano, P. Sartor \& G. Ardizzone. 2009. Identifying fish nurseries using density and persistence measures. Marine Ecology Progress Series, 381: 287-296.

Elsdon, T. S. \& B. M. Gillanders. 2002. Interactive effects of temperature and salinity on otolith chemistry: challenges for determining environmental histories of fish. Canadian Journal of Fisheries and Aquatic Sciences, 59: 1796-1808.

Elsdon, T. S. \& B. M. Gillanders. 2005. Alternative life-history patterns of estuarine fish: barium in otoliths elucidates freshwater residency. Canadian Journal of Fisheries and Aquatic Sciences, 62: 1143-1152.

Espinach Ros, A. A., L. D. Demonte, M. Campana, A. Trogolo, A. Dománico \& E. Cordiviola. 2008. Estimación de edades y crecimiento In: Proyecto de evaluación del recurso sábalo (Prochilodus lineatus) en el Paraná. Informe de los resultados de la segunda etapa (2006-2007). Buenos Aires, Secretaría de Agricultura, Ganadería,PescayAlimentos, SubsecretaríadePesca y Acuicultura. Available from: http://www.minagri.gob.ar/site/ pesca/pesca_continental/04=informes/01-baja $\% 20$ cuenca $\% 20$ parana-plata/archivos/_archivos/060000-Segundo $\% 20$ informe $\% 20 \mathrm{del} \% 20$ proyecto $\% 20 \mathrm{de} \% 20$ evaluaci $\% \mathrm{C} 3 \% \mathrm{~B} 3 \mathrm{n} \% 20$ del\%20recurso $\% 20$ del $\% 20$ s\%C $3 \%$ A 1 balo\%20\%2820062007\%29.pdf?PHPSESSID=9b5329f9fdfaa78cfdab8edb94e5 fb72 (Date of access - 31 March 2016).

Espinach Ros, A. \& C. Fuentes. 2000. Recursos pesqueros y pesquerías de la cuenca del plata. Pp. 353-388. In: S. Bezzi, R. Akselman \& E. Boschi (Eds.). Síntesis del Estado de las Pesquerías Marítimas Argentinas y de la Cuenca del Plata. Mar del Plata, Instituto Nacional de Investigación y Desarrollo Pesquero-INIDEP.

Espinach Ros, A. \& P. Sánchez. 2007. Estado de la pesquería de sábalo del rio Paraná y medidas de manejo propuestas. Pp. 52-54. In: Espinach Ros \& A., R. P. Sánchez (Eds). Proyecto de evaluación del recurso sábalo en el Paraná. Informe final de los resultados de la primera etapa 2005-2006 y medidas de manejo recomendadas. Buenos Aires, Secretaría de Agricultura Ganadería, Pesca y Alimentos. Serie Pesca y Acuicultura: Estudios e Investigaciones Aplicadas. Available from: http://www.minagri.gob.ar/site/pesca/pesca continental $/ 04=$ informes $/ 01$-baja $\% 20$ cuenca $\% 20$ paranaplata/_archivos/_archivos/050000-Primer\%20informe $\% 20$ del $\% 20$ proyecto $\% 20 \mathrm{de} \% 20$ evaluaci $\%$ C3\%B3n $\% 20 \mathrm{del} \% 20$ recurso \%20del\%20s\%C3\%A1balo\%20(2005-2006).pdf.pdf, Buenos Aires, Argentina. (Date of access - 31 March 2016).
Food and Agriculture Organization of the United Nations (FAO). 2014. The state of world fisheries and aquaculture, Roma. Available from: < http://www.fao.org/3/a-i3720e/index.html > (Date of access - 31 March 2016).

Galley, E. A., P. J. Wright \& F. M. Gibb. 2006. Combined methods of otolith shape analysis improve identification of spawning areas of Atlantic cod. ICES Journal of Marine Science, 63: 1710-1717.

Garcez, R. C. S., R. Humston, D. Harbor \& C. E. C. Freitas. 2015. Otolith geochemistry in young-of-the-year peacock bass Cichla temensis for investigating natal dispersal in the Rio Negro (Amazon - Brazil) river system. Ecology of Freshwater Fish,24: 242-251.

Gemmell, J. B., H. Zantop \& L. D. Meinert. 1992. Genesis of the Aguilar zinc-lead-silver deposit, Argentina: contact metasomatic vs. sedimentary exhalative. Economic Geology 87: 2085-2112.

Gierl, C., B. Reichenbacher, J. Gaudant, D. Erpenbeck \& A. Pharisat. 2013. An extraordinary gobioid fish fossil from Southern France. PLOS ONE, 8: e64117.

Gillanders, B. M., K. W. Able, J. A. Brown, D. B. Eggleston \& P. F. Sheridan. 2003. Evidence of connectivity between juvenile and adult habitats for mobile marine fauna: an important component of nurseries. Marine Ecology Progress Series, 247: 281-295

Graham, M. H. 2003. Confronting multicollinearity in ecological multiple regression. Ecology, 84: 2809-2815.

Guerrero, R. A., E. M. Acha, M. B. Framiñan \& C. A. Lasta. 1997. Physical oceanography of the Río de la Plata Estuary, Argentina. Continental Shelf Research, 17: 727-742.

Hegg, J. C., T. Giarrizzo \& B. P. Kennedy. 2015. Diverse early life-history strategies in migratory Amazonian catfish: Implications for conservation and management. PLOS ONE, 10: e0129697.

Hegg, J. C., B. P. Kennedy \& A. K. Fremier. 2013. Predicting strontium isotope variation and fish location with bedrock geology: Understanding the effects of geologic heterogeneity. Chemical Geology, 360-361: 89-98.

Ibañez, A. L., I. G. Cowx \& P. O’Higgins. 2007. Geometric morphometric analysis of fish scales for identifying genera, species \& local populations within the Mugilidae. Canadian Journal of Fisheries and Aquatic Sciences, 64: 1091-1100.

Instituto Nacional de Tecnología Industrial (INTI). 2010 Plan de monitoreo y calidad del recurso hídrio en el río Uruguay., Buenos Aires, Ministerio de Industria y Turismo, Secretaría de Industria, Comercio y de la Pequeña y Mediana Empresa. 51 p. Available from: http://www.inti.gov.ar/pdf/ InfRioUruguay2010.pdf (Date of access - 31 March 2016).

Jaramillo, A. M., A. D. Tombari, V. B. Dura \& M. E. Rodrigo. 2014. Otolith eco-morphological patterns of benthic fishes from the coast of Valencia (Spain). Thalassas, 30: 57-66.

Jørgensen, B. \& J. Rajeswaran. 2005. A Generalization of Hotelling's $T^{2}$. Communications in Statistics - Theory and Methods, 34: 2179-2195.

Kerr, L. A. \& S. E. Campana. 2013. Chemical composition of fish hard parts as anatural marker of fish stocks. Pp. 205- 
234. In: Cadrin, S. X., L. A. Kerr \& S. Mariani (Eds.) Stock Identification Methods: Applications in Fishery Science: 2nd ed. San Diego, Academic Press.

Kinsman, D. J. J. \& H. D. Holland. 1969. The co-precipitation of cations with $\mathrm{CaCO}_{3}$ - IV. The co-precipitation of $\mathrm{Sr}^{2+}$ with aragonite between $16^{\circ}$ and $96^{\circ} \mathrm{C}$. Geochimica et Cosmochimica Acta, 33: 1-17.

Klingenberg, C. P. 2011. MorphoJ: An integrated software package for geometric morphometrics. Molecular Ecology Resources, 11: 353-357.

Lombarte, A. 1992. Changes in otolith area: sensory area ratio with body size and depth. Environmental Biology of Fishes, 33: 405-410.

Lombarte, A., M. Palmer, J. Matallanas, J. Gómez-Zurita \& B. Morales-Nin. 2010. Ecomorphological trends and phylogenetic inertia of otolith sagittae in Nototheniidae. Environmental Biology of Fishes, 89: 607-618.

Longmore, C., K. Fogarty, F. Neat, D. Brophy, C. Trueman, A. Milton \& S. Mariani. 2010. A comparison of otolith microchemistry and otolith shape analysis for the study of spatial variation in a deep-sea teleost, Coryphaenoides rupestris. Environmental Biology of Fishes, 89: 591-605.

Loy, A., S. Busilacchi, C. Costa, L. Ferlin \& S. Cataudella. 2000. Comparing geometric morphometrics and outline fitting methods to monitor fish shape variability of Diplodus puntazzo (Teleostea: Sparidae). Aquacultural Engineering, 21: 271-283.

Mai, A. C. G., M. V. Condini, C. Q. Albuquerque, D. Loebmann, T. D. Saint'Pierre, N. Miekeley \& J. P. Vieira. 2014. High plasticity in habitat use of Lycengraulis grossidens (Clupeiformes, Engraulididae). Estuarine, Coastal and Shelf Science, 141: 17-25.

Márquez, F., J. Robledo, G. E. Peñaloza \& S. Van der Molen. 2010. Use of different geometric morphometrics tools for the discrimination of phenotypic stocks of the striped clam Ameghinomya antiqua (Veneridae) in north Patagonia, Argentina. Fisheries Research, 101: 127-131.

Martin, G. B. \& S. R. Thorrold. 2005. Temperature and salinity effects on magnesium, manganese \& barium incorporation in otoliths of larval and early juvenile spot Leiostomus xanthurus. Marine Ecology Progress Series, 293: 223-232.

Martin, G. B., S. R. Thorrold \& C. M. Jones. 2004. Temperature and salinity effects on strontium incorporation in otoliths of larval spot (Leiostomus xanthurus). Canadian Journal of Fisheries and Aquatic Sciences, 61: 34-42.

Martin, G. B. \& M. J. Wuenschel. 2006. Effect of temperature and salinity on otolith element incorporation in juvenile gray snapper Lutjanus griseus. Marine Ecology Progress Series, 324: 229-239.

Mullon, C., P. Fréon \& P. Cury. 2005. The dynamics of collapse in world fisheries. Fish and Fisheries, 6: 111-120.

Neiff, J. J. \& A. I. Malvárez. 1999. El régimen de pulsos en ríos y grandes humedales de Sudamérica. Pp. 99-150. In: Malvárez, A. I. (Ed.) Topicos sobre humedales subtropicales y templados de Sudamérica, Montevideo, Oficina Regional de Ciencia y Tecnología de la UNESCO para América Latina y el Caribe (ORCYT).
Nelson, K., E. S. Hutchinson, G. Li, F. L. Sly \& D. Hedgecock. 1994. Variation in life-history and morphology in northern anchovies (Engraulis mordax). California Cooperative Oceanic Fisheries Investigations Reports, 35: 108-120.

Niklitschek, E. J., D. H. Secor, P. Toledo, A. Lafon \& M. GeorgeNascimento. 2010. Segregation of SE Pacific and SW Atlantic southern blue whiting stocks: integrating evidence from complementary otolith microchemistry and parasite assemblage approaches. Environmental Biology of Fishes, 89: 399-413.

Poulet, N., Y. Reyjol, H. Collier \& S. Lek. 2005. Does fish scale morphology allow the identification of populations at a local scale? A case study for rostrum dace Leuciscus leuciscus burdigalensis in River Viaur (SW France). Aquatic Sciences, 67: 122-127.

Ranaldi, M. M. \& M. M. Gagnon. 2008. Zinc incorporation in the otoliths of juvenile pink snapper (Pagrus auratus Forster): The influence of dietary versus waterborne sources. Journal of Experimental Marine Biology and Ecology, 360: 56-62.

Reichenbacher, B. \& M. Reichard. 2014. Otoliths of five extant species of the annual killifish Nothobranchius from the east African Savannah. PLOS ONE, 9: e112459.

Richards, R. A. \& C. Esteves. 1997. Use of scale morphology for discriminating wild stocks of Atlantic Striped Bass. Transactions of the American Fisheries Society, 126: 919-925.

Rohlf, F. J. 2001. TPS Dig 1.31 and TPS relative wards software. State University of New York at Stony Brook, New York.

Rooker, J. R., D. H. Secor, V. S. Zdanowicz \& T. Itoh. 2001. Discrimination of northern bluefin tuna from nursery areas in the Pacific Ocean using otolith chemistry. Marine Ecology Progress Series, 218: 275-282.

Organización de los Estados Americanos (OEA). 1971. Cuenca del Río de la Plata: estudio para su planificación y desarrollo. Inventario y análisis de la información básica sobre recursos naturales. Washington, D.C. pp. 187.

Secor, D. H. \& J. R. Rooker. 2000. Is otolith strontium a useful scalar of life cycles in estuarine fishes? Fisheries Research, 46: 359-371.

Fang, J., B. Gao, Y. Sun, M. Zhang \& S. k. Sharma. 2015. Use the industrial and agricultural waste in removal of heavy metal in water. Pp. 281-295. In: Sharma, S. K. (ed). Heavy metals in water: presence, removal and safety. Royal Society of Chemistry, Cambridge. 357p.

Silva, D. M., P. Santos \& A. T. Correia. 2011. Discrimination of Trisopterus luscus stocks in northern Portugal using otolith elemental fingerprints. Aquatic Living Resources, 24: 85-91.

Sinclair, D. J., L. P. J. Kinsley \& M. T. McCulloch. 1998. High resolution analysis of trace elements in corals by laser ablation ICP-MS. Geochimica et Cosmochimica Acta, 62: 1889-1901.

Stanley, R., I. R. Bradbury, C. DiBacco, P. V. R. Snelgrove, S. R. Thorrold \& S. S. Killen. 2015. Environmentally mediated trends in otolith composition of juvenile Atlantic cod (Gadus morhua). ICES Journal of Marine Science, 71: 236-240.

Sturrock, A. M., C. N. Trueman, A. M. Darnaude \& E. Hunter. 2012. Can otolith elemental chemistry retrospectively track migrations in fully marine fishes? Journal of Fish Biology, 81: 766-795. 
Sverlij, S. B., A. Espinach Ros \& G. Ortí. 1993. Synopsis de los datos biologicos del sabalo Prochilodus lineatus (Valenciennes, 1847). Roma, Food and Agriculture Organization of the United Nations - FAO Sinopsis sobre la Pesca 154. 64p.

Tabouret, H., G. Bareille, F. Claverie, C. Pécheyran, P. Prouzet \& O. F. X. Donard. 2010. Simultaneous use of strontium:calcium and barium:calcium ratios in otoliths as markers of habitat: Application to the European eel (Anguilla anguilla) in the Adour basin, South West France. Marine Environmental Research, 70: 35-45.

Tournois, J., F. Ferraton, L. Velez, D. J. McKenzie, C. Aliaume, L. Mercier \& A. M. Darnaude. 2013. Temporal stability of otolith elemental fingerprints discriminates among lagoon nursery habitats. Estuarine, Coastal and Shelf Science, 131: 182-193.

Tuset, V. M., E. Azzurro \& A. Lombarte. 2012. Identification of Lessepsian fish species using the sagittal otolith. Scientia Marina, 76: 289-299.

Tuset, V. M., A. Lombarte, J. A. González, J. F. Pertusa \& M. J. Lorente. 2003a. Comparative morphology of the sagittal otolith in Serranus spp. Journal of Fish Biology, 63: 1491-1504.

Tuset, V. M., I. J. Lozano, J. A. Gonzĺez, J. F. Pertusa \& M. M. García-Díaz. 2003b. Shape indices to identify regional differences in otolith morphology of comber, Serranus cabrilla (L., 1758). Journal of Applied Ichthyology, 19: 88-93.

Tuset, V. M., V. Parisi-Baradad \& A. Lombarte. 2013. Application of otolith mass and shape for discriminating scabbardfishes Aphanopus spp. in the north-eastern Atlantic Ocean. Journal of Fish Biology, 82: 1746-1752.
U. S. Environemntal Protection Agency (USEPA). 1994. Determination of metals and trace elements in water and wastes by Inductively Coupled Plasma-Atomic Spectrometry. EPA Method 200.7. Ohio, USEPA. 58p.

Walther, B. D. \& S. R. Thorrold. 2009. Inter-annual variability in isotope and elemental ratios recorded in otoliths of an anadromous fish. Journal of Geochemical Exploration, 102: 181-186.

Zelditch, M. L., D. L. Swiderski, H. D. Sheets \& W. L. Fink. 2004. Geometric morphometrics for biologists: a primer. San Diego, Elsevier Academic Press. 457p.

Zelditch, M. L., D. L. Swiderski \& H. D. Sheets. 2012. Geometric morphometrics for biologists: a primer. Elsevier Academic Press. 488p.

Zhuang, L., Z. Ye \& C. Zhang. 2014. Application of otolith shape analysis to species separation in Sebastes spp. from the Bohai Sea and the Yellow Sea, northwest Pacific. Environmental Biology of Fishes, 98: 547-558.
Submitted April 01, 2016

Accepted June 08, 2016 by Franco Teixeira de Mello 